\title{
PENGEMBANGAN KARTU BERGAMBAR SAINS SEBAGAI MEDIA \\ PEMBELAJARAN BIOLOGI POKOK BAHASAN SISTEM DALAM KEHIDUPAN TUMBUHAN KELAS VIII MTS DARUL AMAN SELAGALAS TAHUN PELAJARAN 2015/2016
}

\author{
Jamiatul Hasanah ${ }^{1}$, Dwi Wahyudiati ${ }^{2}$ dan Hadi Kusuma \\ Ningrat $^{3}$ \\ 1Jurusan Pendidikan IPA Biologi FITK IAIN Mataram \\ 2,3Dosen Jurusan Pendidikan IPA Biologi FITK IAIN Mataram
}

\begin{abstract}
Abstrak
Jenis penelitian yang digunakan yaitu penelitian dan pengembangan. Dimana tujuan penelitian dan pengembangan kartu bergambar sains ini digunakan sebagai media pembelajaran biologi pokok bahasan sistem dalam kehidupan tumbuhan kelas VIII Mts. Darul Aman Selagalas Tahun Pelajaran 2015/2016, sedangkan untuk mengembangkan kartu bergambar sains sebagai media pembelajaran biologi ini digunakan Model Pengembangan Dick \& Carrey, yang mencakup 10 langkah pengembangan. Dalam pengembangan ini tidak semua langkah pengembangan Dick \& Carrey digunakan, tetapi hanya sampai langkah ke sembilan yaitu merevisi produk pengembangan. Pada tahap/langkah ke delapan pengembangan ini dilakukan evaluasi formatif (uji ahli isi,uji ahli media, uji ahli bahasa, uji kelompok kecil dan uji lapangan). (a) uji ahli isi dengan persentase hasil review sebesar $90 \%$ yang berarti produk pengembangan tidak direvisi; (b) uji ahli media dengan persentase hasil review sebesar $80 \%$ yang berarti produk pengembangan tidak perlu direvisi; (c) uji ahli bahasa dengan persentase hasil review sebesar $80 \%$ yang berarti produk pengembangan tidak direvisi; (d) uji kelompok kecil dengan persentase hasil penilaian/tanggapan sebesar 75,21\% yang berarti produk pengembangan tidak perlu direvisi; dan (e) uji coba lapangan dengan persentase hasil penilaian/tanggapan sebesar $80,63 \%$ yang berarti produk pengembangan tidak perlu direvisi dan dinyatakan "Valid".
\end{abstract}

Kata Kunci: Pengembangan, Kartu Bergambar Sains, Media Pembelajaran Biologi 


\section{PENDAHULUAN}

Terdapat beberapa hal yang dapat menyebabkan materi kehidupan tumbuhan dianggap tidak menarik, yaitu cara guru mengajarkan materi dengan buku teks, selalu menggunakan metode ceramah dan kurangnya sarana prasarana yang mendukung dalam proses belajar yang membuat siswa jenuh dan sulit memahaminya, dan modal awal siswa yang akan mempelajari materi tersebut ${ }^{1}$. Siswa akan belajar manakala mereka memiliki motivasi yang kuat untuk belajar. Oleh sebab itu penggunaan metode pembelajaran dan media yang di kembangkan harus sesuai dengan minat dan kebutuhan siswa itu sendiri. Media yang menarik akan mendorong siswa untuk mempelajarinya dengan baik ${ }^{2}$.

Menurut peneliti, pemikiran tersebut cukup relevan dilaksanakan untuk siswa MTs. Darul Aman Selagalas. Siswa MTs. Darul Aman dalam hal keagamaan ditekankan dalam kegiatan menghapal Al-Qur'an. Mereka bisa dikatakan sedikit waktu untuk istirahat dan mengulang pelajaran yang sudah dipelajari di dalam kelas atau mempersiapkan materi yang akan dipelajari besok di kelas dan kebiasaan mereka sering tertidur di saat jam pelajaran berlangsung ${ }^{3}$.

Berdasarkan uraian di atas, peneliti menemukan berbagai bentuk permasalahan yang ditemukan di sekolah khususnya dari segi kurangnya minat siswa dalam memahami materi, sehingga peneliti melakukan penelitian pada permasalahan tersebut ke dalam suatu penelitian pengembangan dengan judul "Pengembangan Kartu Bergambar Sains Sebagai Media Pembelajaran Biologi P okok Bahasan Sistem dalam Kehidupan Tumbuhan Kelas VIII di MTs. Darul Aman Selagalas tahun pelajaran 2015/2016.

Salah satu cara untuk membangkitkan motivasi belajar siswa dalam keadaan tersebut adalah dengan penggunaan media yang tepat dalam pembelajaran. Menurut Hamalik sebagaimana dikutip oleh Arsyad bahwa pemakaian media pembelajaran dalam proses belajar dapat membangkitkan keinginan dan minat yang baru, membangkitkan motivasi dan rangsangan kegiatan 
belajar, dan bahkan membawa pengaruh-pengaruh psikologis terhadap siswa.

\section{METODE PENELITIAN}

\section{Model pengembangan}

Model pengembangan yang digunakan dalam pengembangan kartu bergambar sains sebagai media pembelajaran biologi ini adalah model pengembangan Dick \& Carrey. Dimana urutan pengembangan Model Dick \& Carrey tergambar sebagai berikut: (1) mengidentifikasi tujuan umum pengajaran; (2) melakukan analisis pembelajaran; menganalisa siswa dan konteks; (4) merumuskan tujuan khusus; (5) mengembangkan instrumen penilaian; (6) mengembangkan strategi pembelajaran; (7) mengembangkan dan memilih kartu bergambar sains biologi;(8) merancang dan melaksanakan evaluasi formatif; (9) merevisi bahan ajar; (10) merancang dan melaksanakan evaluasi sumatif 4 . Langkah ke-10 tidak digunakan dalam pengembangan ini, karena terkait kebutuhan pengembang dan keterbatasan waktu serta biaya.

Kesepuluh langkah pada model Dick \& Carrey tersebut menunjukkan hubungan yang sangat jelas, dan tidak terputus antara langkah yang satu dengan langkah yang lainnya. Dengan kata lain, sistem yang terdapat pada model tersebut sangat ringkas, namun isinya padat dan jelas dari satu urutan ke urutan berikutnya.

\section{Uji Coba Produk}

Uji coba produk yang dimaksud untuk mendapatkan data sebagai dasar untuk melakukan perbaikan terhadap produk supaya mendapatkan produk pengembangan dapat mencapai tingkat efektifitas dan daya tarik sesuai dengan harapan. Uji coba produk dalam penelitian pengembangan ini meliputi 


\section{a. Desain Uji Coba}

Uji coba dilakukan untuk mendapatkan data yang dilakukan sebagai dasar untuk merevisi produk. Sebelum diujicobakan, produk dievaluasi oleh 3 orang ahli yaitu ahli teori biologi, ahli media, dan ahli bahasa pembelajaran yang disebut dengan uji validitas. Uji coba yang dilakukan melalui beberapa tahap, yaitu (1) review ahli isi, review ahli media, dan review ahli bahasa; (2) uji coba kelompok kecil; dan (3) uji coba lapangan.

\section{b. Instrumen Pengumpulan Data}

Instrumen yang digunakan dalam penggumpulan data adalah sebagai berikut: Dokumentasi, Angket, dan Wawancara (kegiatan ini dilakukan oleh peneliti untuk mendapatkan informasi yang lebih luas dan belum bisa dijawab oleh instrumen-instrumen dari angket).

\section{c. Teknik Analisis Data}

Dalam penelitian \& pengembangan ini data-data yang dihimpun dari hasil review ahli dan uji coba produk pengembangan berupa kartu bergambar sains sebagai media pembelajaran biologi digunakan dua teknik analisis yaitu:

- Analisis Deskriptif Kualitatif

Teknik analisis deskriptif kualitatif ini digunakan untuk mengolah data hasil review ahli isi, ahli media, ahli bahasa, dan siswa. Teknik analisis data ini dilakukan dengan mengelompokkan informasi- informasi dari data kualitatif yang berupa masukan, tanggapan, kritikan, dan saran perbaikan yang terdapat pada angket dan wawancara. Hasil analisis ini kemudian digunakan untuk merevisi produk media kartu pembelajaran sains. 
- Analisis Statistik Deskriptif

Teknik analisis statistik deskriptif digunakan untuk mengolah data yang diperoleh melalui angket dalam bentuk deskriptif persentase dengan menggunakan rumus Skala Likert. Rumus yang digunakan untuk menghitung persentase keberhasilan produk, yaitu: ${ }^{5}$

$$
\text { Indeks } \%=\frac{\text { Jumlah Skor X } \quad 100 \%}{\text { Jumlah Skor Tertinggi }}
$$

Selanjutnya, untuk menghitung persentase keseluruhan subyek digunakan rumus: 6

$$
\mathbf{P}=\frac{\sum p}{\sum n} \times 100 \%
$$

Keterangan:

$$
\begin{array}{ll}
\mathrm{P} & =\text { Presentase penilaian } \\
\sum \mathrm{p} & =\text { Jumlah skor } \mathrm{x} \text { Frekuensi jawaban } \\
\sum \mathrm{n} & =\text { Jumlah skor tertinggi } \mathrm{x} \text { jumlah siswa. }
\end{array}
$$

Untuk dapat memberikan makna dan pengambilan keputusan digunakan ketetapan sebagai berikut: ${ }^{7}$

\section{Tabel 1}

Konversi Tingkat Kelayakan Penggunaan Kartu Bergambar Sains sebagai Media Pembelajaran Biologi Pokok Bahasan Sistem Kehidupan Tumbuhan.

\begin{tabular}{|l|c|c|}
\hline Interval & Kualitatif & Keterangan \\
\hline $0 \%-54 \%$ & Tidak valid & Direvisi \\
\hline $55 \%-64 \%$ & Kurang & Direvisi \\
\hline $65 \%-74 \%$ & Cukup & Direvisi \\
\hline $75 \%-89 \%$ & Valid & Tidak perlu revisi \\
\hline $90 \%-100 \%$ & Sangat valid & Tidak perlu revisi \\
\hline
\end{tabular}




\section{HASIL DAN PEMBAHASAN}

\section{Hasil Uji Ahli Isi (Review Ahli Isi)}

Produk pengembangan ini berupa kartu bergambar sains sebagai media pembelajaran biologi pokok bahasan sistem kehidupan tumbuhan untuk MTs. kelas VIII. Untuk uji validasi isi/materi media kartu ini, ahli isi/materi (validator isi) yang digunakan adalah Bapak Firman Syah, S.Pd.I beliau adalah salah satu guru di MTs. Darul Aman yang mengajar mata pelajaran IPA Biologi. Produk pengembangan ini diserahkan kepada ahli isi pada hari Kamis, tanggal 18 Mei 2016 dan bertemu kembali hari Senin, tanggal 23 Mei 2016. Berikut adalah paparan hasil dari review ahli isi terhadap produk pengembangan ini melalui metode angket dan diskusi.

\section{a. Penyajian Data dan Analisis Data}

Penilaian yang dilakukan oleh ahli isi dilakukan dengan cara pemberian skor pada setiap item yang ada dalam angket. Berikut komentar, saran, serta masukan perbaikan sekiranya terdapat kekurangan dan kekeliruan. Rentang skor dalam angket yang diberikan adalah skor 1 (sangat tidak valid, sangat tidak sesuai, sangat tidak jelas, sangat tidak menarik, sangat tidak mudah); skor 2 (kurang valid, kurang sesuai, kurang jelas, kurang menarik, kurang mudah); skor 3 (cukup valid, cukup sesuai, cukup jelas, cukup menarik, cukup mudah); skor 4 (valid, sesuai, menarik, mudah); dan skor 5 (sangat valid, sangat sesuai, sangat menarik, sangat mudah). Berikut adalah penyajian data dari hasil review ahli isi dengan melakukan analisis data yang sudah didapatkan dari angket dengan menggunakan rumus Skala Likert. 


\section{Tabel 2}

Hasil Review Ahli Isi Materi

\begin{tabular}{|c|c|c|}
\hline Jumlah Item & Skor & Frekuensi \\
\hline \multirow{3}{*}{8} & 5 & 4 \\
\cline { 2 - 3 } & 4 & 4 \\
\cline { 2 - 3 } & 3 & 0 \\
\cline { 2 - 3 } & 2 & 0 \\
\cline { 2 - 3 } & 1 & 0 \\
\hline \multicolumn{2}{|c}{ Jumlah } & 8 \\
\hline
\end{tabular}

Data yang didapatkan dari hasil angket ahli isi di atas kemudian diolah dengan cara mengkalikan setiap poin yang sudah ditentukan dengan tabel bobot nilai. Maka hasil perhitungan jawaban skor responden dari ahli isi yaitu:

1) Jumlah skor 5 untuk frekuensi 4 adalah : $5 \times 4=20$

2) Jumlah skor 4 untuk frekuensi 4 adalah : $4 \times 4=16$

3) Jumlah skor 3 untuk frekuensi 0 adalah : $3 \times 0=0$

4) Jumlah skor 2 untuk frekuensi 0 adalah : $2 \times 0=0$

5) Jumlah skor 1 untuk frekuensi 0 adalah : $1 \times 0=0$

Jadi, total seluruh skor adalah : $20+16+0+0+0=36$

Untuk mendapatkan hasil responden ahli isi, maka harus diketahui dulu skor tertinggi (X) dan skor terendah (Y) untuk item penilaiannya, yaitU: (X) Jumlah skor ideal/ skor teringgi adalah $5 \times 8=40(\mathrm{Y})$ Jumlah skor terendah adalah $1 \times 8=8$

Berdasarkan skor tertinggi (X) yang diperoleh, maka tingkat kelayakan menurut ahli isi terhadap penggunaan media kartu bergambar sains sebagai media pembelajaran biologi pokok bahasan sistem kehidupan tumbuhan untuk MTs. Kelas VIII dapat dihitung dengan menggunakan rumus Skala Likert yaitu:

$$
\begin{aligned}
\text { Indenks \% } & =\underbrace{\text { Jumlah Skor X 100\% }}_{\text {Jumlah Skor tertinggi }} \\
& =36 / 40 \times 100 \%=90 \%
\end{aligned}
$$


Setelelah dikonversikan dengan tabel konversi dapat disimpulkan bahwa menurut ahli isi, produk kartu bergambar sains sebagai media pembelajaran biologi pokok bahasan sistem kehidupan tumbuhan untuk MTs. kelas VIII menunjukkan bahwa produk ini berada dalam kualifikasi sangat valid sehingga tidak perlu dilakukan revisi.

\section{Hasil Uji Ahli Media (Review Ahli Media)}

Produk pengembangan berupa kartu bergambar sains sebagai media pembelajaran biologi pada sistem kehidupan tumbuhan dengan menggunakan instrumen berupa angket diserahkan pada hari Selasa, tanggal 17 Mei 2016 dan bertemu kembali hari Kamis, tanggal 19 Mei 2016. Dosen ahli media yang diminta untuk mereview produk pengembangan adalah Ibu Nurdiana, SP, MP. Ahli media merupakan salah satu dosen tetap di Jurusan IPA Biologi IAIN Mataram yang mengampuh mata kuliyah taksonomi tumbuhan tinggi (TTT) dan morfologi tumbuhan, Penyajian Data dan Analisis Data.

Tabel 3

Hasil Review Ahli Media

\begin{tabular}{|c|c|c|}
\hline Jumlah Item Pertanyaan & Skor & Frekuensi \\
\hline \multirow{3}{*}{7} & 5 & 1 \\
\cline { 2 - 3 } & 4 & 5 \\
\cline { 2 - 3 } & 3 & 1 \\
\cline { 2 - 3 } & 2 & 0 \\
\cline { 2 - 3 } & 1 & 0 \\
\hline \multicolumn{2}{|c|}{ Jumlah } & 7 \\
\hline
\end{tabular}

Data yang didapatkan dari hasil angket ahli media di atas kemudian diolah dengan cara mengkalikan setiap poin yang sudah ditentukan dengan tabel bobot nilai. Maka hasil perhitungan jawaban skor responden dari ahli media yaitu:

1) Jumlah skor 5 untuk frekuensi 1 adalah : $5 \times 1=5$

2) Jumlah skor 4 untuk frekuensi 1 adalah : $4 \times 5=20$

3) Jumlah skor 3 untuk frekuensi 1 adalah : $3 \times 1=3$

4) Jumlah skor 2 untuk frekuensi 1 adalah : $2 \times 0=0$

5) Jumlah skor 1 untuk frekuensi 1 adalah : $1 \times 0=0$

Jadi, total seluruh skor adalah $: 5+20+3+0+0=28$

248 BIOTA: Jurnal Tadris IPA Biologi FITK IAIN Mataram 
Untuk mendapatkan hasil responden ahli isi, maka harus diketahui dulu skor tertinggi $(\mathrm{X})$ dan skor terendah (Y) untuk item penilaiannya, yaitu:

(X) Jumlah skor ideal/ skor teringgi adalah : $5 \times 7=35$

(Y) Jumlah skor terendah adalah $\quad: 1 \times 7=7$

Berdasarkan skor tertinggi (X) yang diperoleh, maka tingkat kelayakan menurut ahli media terhadap penggunaan kartu bergambar sains sebagai media pembelajaran biologi pokok bahasan sistem kehidupan tumbuhan untuk MTs. Kelas VIII dapat dihitung dengan menggunakan rumus Skala Likert yaitu:

$$
\begin{aligned}
\text { Indeks } \% & =\frac{\text { Jumlah Skor X 100\% }}{\text { Jumlah Skor tertinggi }} \\
& =28 / 35 \times 100 \% \\
& =80 \%
\end{aligned}
$$

Setelelah dikonversikan dengan tabel konversi menunjukkan bahwa produk pengembangan berupa kartu bergambar sains sebagai media pembelajaran biologi pokok bahasan sistem kehidupan tumbuhan untuk MTs. kelas VIII berada dalam kualifikasi valid sehingga tidak perlu dilakukan revisi.

\section{Hasil Uji Ahli Bahasa (Review Ahli Bahasa)}

Produk pengembangan kartu bergambar sains sebagai media pembelajaran biologi pokok bahasan sistem kehidupan tumbuhan dan instrumen berupa angket diserahkan pada hari Kami, tanggal 18 Mei 2016 dan bertemu kembali hari Selasa, tanggal 24 Mei 2016. Dosen ahli bahasa yang diminta untuk mereview produk pengembangan adalah Bapak M. Zulpiani Hamdi, M.Pd. Ahli bahasa merupakan salah satu dosen tetap yang di jurusan Pendidikan IPA Biologi IAIN 
Mataram yang mengampu mata kuliyah Bahasa Inggris. Penyajian Data dan Analisis Data.

\section{Tabel 4}

Hasil Review Ahli Bahasa

\begin{tabular}{|c|c|c|}
\hline Jumlah Item Pertanyaan & Skor & Frekuensi \\
\hline \multirow{3}{*}{5} & 5 & 1 \\
\cline { 2 - 3 } & 4 & 3 \\
\cline { 2 - 3 } & 3 & 1 \\
\cline { 2 - 3 } & 2 & 0 \\
\cline { 2 - 3 } & 1 & 0 \\
\hline \multicolumn{2}{|c|}{ Jumlah } & 5 \\
\hline
\end{tabular}

Data yang didapatkan dari hasil angket ahli bahasa di atas kemudian diolah dengan cara mengkalikan setiap poin yang sudah ditentukan dengan tabel bobot nilai. Maka hasil perhitungan jawaban skor responden dari ahli bahasa yaitu:

1) Jumlah skor 5 untuk frekuensi 1 adalah : $5 \times 1=5$

2) Jumlah skor 4 untuk frekuensi 1 adalah : $4 \times 3=12$

3) Jumlah skor 3 untuk frekuensi 1 adalah : $3 \times 1=3$

4) Jumlah skor 2 untuk frekuensi 1 adalah : $2 \times 0=0$

5) Jumlah skor 1 untuk frekuensi 1 adalah : $1 \times 0=0$ Jadi, total seluruh skor adalah $\quad: 5+12+3+0+0=20$

Untuk mendapatkan hasil responden ahli isi, maka harus diketahui dulu skor tertinggi (X) dan skor terendah (Y) untuk item penilaiannya, yaitu:

(X) Jumlah skor ideal/ skor teringgi adalah : $5 \times 5=25$

(Y) Jumlah skor terendah adalah $\quad: 1 \times 5=5$

Berdasarkan skor tertinggi yang diperoleh, maka tingkat kelayakan menurut ahli bahasa terhadap penggunaan kartu bergambar sains sebagai media pembelajaran biologi pokok bahasan sistem kehidupan tumbuhan untuk MTs. kel ung dengan menggunakan rumus Skala Likert yaitu: 


$$
\begin{aligned}
\text { Indeks \% } & =\frac{\text { Jumlah Skor X 100\% }}{\text { Jumlah Skor tertinggi }} \\
& =20 / 25 \times 100 \% \\
& =80 \%
\end{aligned}
$$

Setelelah dikonversikan dengan tabel konversi (halaman 64) menunjukkan bahwa produk pengembangan berupa kartu bergambar sains sebagai media pembelajaran biologi pokok bahasan sistem kehidupan tumbuhan untuk MTs. kelas VIII berada dalam kualifikasi valid sehingga tidak perlu dilakukan revisi.

\section{Uji Kelompok Kecil}

\section{a. Penyajian dan Analisis Data}

Uji kelompok kecil dilakukan pada hari Rabu, tanggal 18 Mei 2016 dan bertemu kembali pada hari Senin, tanggal 23 Mei 2016. Berikut ini disajikan data yang diperoleh dari uji coba kelompok kecil pada produk pengembangan kartu bergambar sains sebagai media pembelajaran biologi pokok bahasan sistem kehidupan tumbuhan untuk MTs. kelas VIII.

\section{Tabel 5}

Data Hasil Uji Coba Kelompok Kecil Terhadap

Produk Pengembangan

\begin{tabular}{|c|c|c|c|c|c|l|l|l|}
\hline \multirow{2}{*}{$\begin{array}{c}\text { Item } \\
\text { Pertanyaan }\end{array}$} & \multicolumn{6}{|c|}{$\begin{array}{c}\text { Frekuensi Dengan } \\
\text { Skala 5 }\end{array}$} & \multirow{2}{*}{ Jml } & \multirow{2}{*}{$\begin{array}{l}\text { Komentar } \\
\text { / Saran }\end{array}$} \\
\cline { 2 - 8 } & $\mathbf{1}$ & $\mathbf{2}$ & $\mathbf{3}$ & $\mathbf{4}$ & $\mathbf{5}$ & & & \\
\hline $\mathbf{1}$ & & 2 & 4 & 3 & 3 & 12 & 71,67 & \\
\hline $\mathbf{2}$ & & 2 & 2 & 4 & 4 & 12 & 76,67 & \\
\hline $\mathbf{3}$ & & 1 & 5 & 4 & 2 & 12 & 71,67 & \\
\hline $\mathbf{4}$ & & & 5 & 3 & 4 & 12 & 78,33 & \\
\hline $\mathbf{5}$ & 1 & & 5 & 4 & 2 & 12 & 75,01 & \\
\hline $\mathbf{6}$ & & 1 & 3 & 4 & 4 & 12 & 78,33 & \\
\hline $\mathbf{7}$ & & 1 & 3 & 4 & 4 & 12 & 78,33 & \\
\hline $\mathbf{8}$ & & 2 & 3 & 5 & 2 & 12 & 71,67 & \\
\hline Jumlah & & & & & & & 601,68 & \\
\hline Rata-rata & & & & & & & 75,21 & \\
\hline
\end{tabular}


Berdasarkan penilaian/tanggapan sebagaimana tercantum dalam tabel 5 di atas, diketahui bahwa rata-rata presentase tingkat pencapaian kartu bergambar sains sebagai media pembelajaran biologi pokok bahasan sistem kehidupan tumbuhan untuk MTs. kelas VIII yaitu 75,21\%. Rerata tersebut bila dikonversikan dengan tabel kelayakan (halaman 64), maka produk pengembangan berupa kartu bergambar sains sebagai media pembelajaran biologi pokok bahasan sistem kehidupan tumbuhan untuk MTs. kelas VIII berada pada kualifikasi valid dan tidak perlu direvisi.

\section{Uji Coba Lapangan}

Hasil review berdasarkan saran, masukan dan komentar siswa dalam uji coba kelompok kecil. Draf pengembangan tersebut selanjutnya dibawa ke kelas untuk dilakukan uji coba lapangan. Uji coba lapangan dilakukan di MTs. Darul Aman yang berjumlah 24 orang siswa kelas VIII. Produk pengembangan yang diuji coba pada siswa berupa kartu bergambar sains sebagai media pembelajaran biologi pokok bahasan sistem kehidupan tumbuhan. Selanjutnya siswa diberikan draf hasil revisi uji coba kelompok kecil dan angket tanggapan untuk uji coba lapangan.

\section{Tabel 6}

Data Hasil Uji Coba Lapangan Terhadap

Produk Pengembangan

\begin{tabular}{|c|c|c|c|c|c|c|c|c|}
\hline \multirow{2}{*}{$\begin{array}{c}\text { Item } \\
\text { Pertanyaan }\end{array}$} & \multicolumn{6}{|c|}{ Frekuensi Dengan Skala 5 } & \multirow{2}{*}{ Jml } & \multirow{2}{*}{$\begin{array}{c}\text { Komentar/ } \\
\text { Saran }\end{array}$} \\
\hline & $\mathbf{1}$ & $\mathbf{2}$ & $\mathbf{3}$ & $\mathbf{4}$ & $\mathbf{5}$ & & & \\
\hline $\mathbf{1}$ & & 1 & 9 & 11 & 3 & 24 & 73,34 & \\
\hline $\mathbf{2}$ & & 3 & 4 & 6 & 11 & 24 & 92,50 & \\
\hline $\mathbf{3}$ & & 5 & 3 & 9 & 7 & 24 & 75.00 & \\
\hline $\mathbf{4}$ & & 2 & 4 & 5 & 13 & 24 & 84,17 & \\
\hline $\mathbf{5}$ & & & 8 & 5 & 11 & 24 & 82,50 & \\
\hline $\mathbf{6}$ & & 4 & 8 & 8 & 4 & 24 & 70,01 & \\
\hline $\mathbf{7}$ & & & 6 & 12 & 6 & 24 & 80,00 & \\
\hline $\mathbf{8}$ & & & 5 & 5 & 14 & 24 & 87,50 & \\
\hline Jumlah & & & & & & & $\mathbf{6 4 5 , 0 2}$ & \\
\hline Rata-rata & & & & & & & $\mathbf{8 0 , 6 3}$ & \\
\hline
\end{tabular}


Berdasarkan hasil uji coba lapangan sebagaimana tercantum pada tabel 6 di atas, skor yang diperoleh dari 8 instrumen pertanyaan yang diajukan pada kelas VIII B MTs. Darul Aman yang jumlah siswanya yaitu 24 orang. Rerata persentase diperoleh sebesar 80,63\%. Setelah dikonversikan dengan tabel konversi (halaman 64) diketahui bahwa produk pengembangan kartu bergambar sains sebagai media pembelajaran biologi pokok bahasan sistem kehidupan tumbuhan pada MTs. kelas VIII berada dalam kualifikasi valid dan tidak perlu direvisi, tetapi media kartu ini tetap direvisi dengan masukan dan saran pada uji lapangan.

\section{KESIMPULAN}

Kartu bergambar sains sebagai media pembelajaran biologi pokok bahasan sistem kehidupan tumbuhan pada kelas VIII ini sebagai produk pengembangan media pembelajaran yang digunakan oleh siswa MTs. Darul Aman kelas VIII khususnya pada materi sistem kehidupan tumbuhan. Adapun hasil penelitian pengembangan kartu bergambar sains sebagai media pembelajaran biologi pokok bahasan sistem kehidupan tumbuhan yaitu dari uji ahli isi/materi dengan peresentase hasil review sebesar $90 \%$ yang berarti produk pengembangan tidak direvisi, uji ahli media dengan peresentase hasil review sebesar $80 \%$ yang berarti produk pengembangan tidak direvisi, uji ahli bahasa dengan peresentase hasil review sebesar $80 \%$ yang berarti produk pengembangan tidak direvisi, uji coba kelompok kecil dilakukan oleh dua belas orang siswa dengan peresentase hasil penilaian/tanggapan sebesar $75,21 \%$ yang berarti produk pengembangan tidak perlu direvisi, dan uji lapangan dilakukan oleh semua siswa kelas VIII B MTs. Darul Aman yang berjumlah 24 orang siswa dengan persentase hasil penilaian/tanggapan sebesar 77\% yang berarti produk pengembangan tidak perlu direvisi dan dinyatakan "Valid". 


\section{DAFTAR PUSTAKA}

Amirudin. Pengembangan Media Komik Sains Biologi Melalui Pembelajaran CTL Materi Sisitem Pencernaan. Mataram: IAIN Mataram, 2015.

Arief Sadiman, Rahardjo, dkk. Media Pendidikan. Jakarta: Rajawali, 2014.

Ayu Amalia. 2015. Pengaruh Model Tgt Media Kartu Bergambar Terhadap Aktivitas Belajar Dan Penguasaan Materi. Lampung: Universitas Lampung. Dalam http://www.google.com/url, diakses tanggal 8 Februari 2016.

Azhar, Arsyad. 2011. Media Pembelajaran. Jakarta: Rajawali

Budi, Susetyo. 2008. Pengembangan Model Pembelajaran Fisika Berbasis Empat Piral Pendidikan. Semarang: Universitas Negeri Semarang, Dalam http://www.google.com/url, diakses tanggal 28 Februari 2016.

Dewi Rosanti. 2013. Morfologi Tumbuhan. Jakarta: Erlangga.

Emzir. 2014. Metodologi Penelitian Pendidikan Kuantitatif dan Kualitatif. Jakarta: Rajawali.

E. Zaenal Arifin dan S. Arman Tasai. 2010. Cermat Berbahasa Indonesia. Jakarta: Akademika Pressindo

Gembong, Tjitrosoepomo. 2011. Morfologi Tumbuhan. Yogyakarta: Gadjah Mada University Press.

Hamzah B. Uno. 2012. Perencanaan Pembelajaran. Jakarta: Bumi Aksara.

Muhibbin Syah. 2013. Psikologi Pendidikan. Bandung: PT Remaja Rosdakarya Offset.

254 BIOTA: Jurnal Tadris IPA Biologi FITK IAIN Mataram 
Nana Syaodih Sukmadinata. Metode Penelitian Pendidikan. Bandung: Rosda, 2015.

Nana Sudjana, Ahmad Rivai, dkk. 2013.Media Pengajaran. Bandung: Sinar Baru Algensindo.

Neil A. Campbell dan Jane B. Reece. 2008. Biologi Edisi Kedelapan Jilid 2. Jakarta: Erlangga

Ngalim, Purwanto. 2010. Prinsip-Prinsip dan Teknik Evaluasi Pengajaran. Bandung: PT Remaja Rosdakarya.

Q A Internasional. 2006. Visual Ilmu dan Pengetahuan Popular. Canada: PT Bahana Ilmu Populer.

Riduwan. 2012. Dasar-Dasar Statistika. Bandung: Alfabeta.

Rifai Mien. 2004. Kamus Biologi. Jakarta: Balai Pustaka

Sardiman. 2014. Intraksi \& Motivasi Belajar Mengajar. Jakarta: Rajawali.

Suharti. 2009. Media Kartu Bergambar untuk Meningkatkan Prestasi Belajar Pendidikan Kewarganegaraan Anak Tunagrahita Sedang. Surakarta: Universitas Sebelas Maret, Dalam http://www.google.com/url, diakses tanggal 8 Februari 2016.

Sugiyono. 2014. Metode Penelitian Pendidikan. Bandung: Alfabeta

Tim Reality. 2009. Kamus Biologi Lengkap. Surabaya: Reality Publisher. 